\title{
POWER AND THE CITY. CAIRO AN ARENA FOR PROFIT, CLASSES DISPUTE OR POLITICAL PROPAGANDA?
}

\author{
Sadek Saad \\ Department of Architectural Engineering \\ Shobra Faculty of Engineering, Benha University, Cairo, Egypt
}

\begin{abstract}
The city can be seen as the end-product of human civilisation, imposing various meninges, it can be an arena for political, economic, sociocultural and classes disputes, imbedding authoritarian power, control and discipline.

This study investigates the architectural and urban traces of authoritarian power, control, and classes disputes in Cairo from around the end of the $18^{\text {th }}$ Century until the first two decades of the $21^{\text {st }}$ Century. The study adopts a descriptive and synthesis research method and approach by relating significant authoritarian urban projects in Cairo to political, economic, and sociocultural forces in action.

The traces of authoritarian power shifted from the celebrative authoritarian architecture level before 1800 to medium-scale urban monumental interventions after the second half of the $19^{\text {th }}$ Century. After 1960 Cairo witnessed several shifts in authoritarian power representation, leading to massive urbanisation and new spectacular capital. Cairo presented various power players shifting nodes along with its urban governance network. The power shift was accompanied by authoritarian control, discipline, and political propaganda while adopting a colonial topdown autocratic urban process.
\end{abstract}

Keywords - Cairo; Urban Studies; Urban Design; Urban History; Authoritarian Power.

\section{INTRODUCTION}

Each physical or spatial urban element reflects a different set of forces bundled together into a network. Layers upon layers of physical and non-physical changes merge, interact and assimilate, 'fusing into a continuum of urban complexity' (Kumar, 2017, p. 1034). It is rather difficult to explain the forces shaping a place without exploring the power network generating and maintaining it. 'We do not deny the powerful structural forces of urban capital' (Pierce et al., 2010, p. 56), but other forces are influential too (Saad, 2017a). Exploring those forces in action can show how they work through particular institutions, networks, and actors (Uitermark et al., 2012).
Rapoport's (Rapoport, 1980) and Alexander's (Alexander, 2002) attempts at reading the urban form and patterns presented the urban components as the end-products of various forces in action. However, it is the forces that shape the place and the type of urban processes (Saad, Forthcoming). In such a perspective, the city shows itself to be an interweaved urban structure reflecting its generating human activities driven by decision-makers and the urban processes' nature. Power is not always about domination and controls; it should also be understood as a general facility for enabling things to happen, the power of decision-making (Allen, 2013, p. 9) and the power to assert the built environment's order (Foucault, 1994). Since architecture and the built environment 'are the products and setting of human action' (Mills, 2012, p. 382), Van der Westhuizen and Cloen (van der Westhuizen and Cloen, 2012, p. 331) argued that the 'spatial logic of both planned and unplanned settlements allows opportunities for placemaking', through the power of decision-making and actions.

Panerai et al. (Panerai et al., 2005) argued that Paris Haussmannisation was imposed to achieve two main urban aims, isolating the new bourgeoisie from other classes and controlling the city. His scheme meant to create a place where the state can achieve urban control and produce economic opportunities for the new bourgeoisie and ruling class (Jordan, 2015). Trying to take more property than the streets required to sell the excess for a profit, 'the scale was small, but the monarchy was powerful' (Jordan, 2015, p. 544). In various parts of the Arab world, such as Damascus, Hudson (Hudson, 2008) pointed out that 'modernisation' and radical changes in social relations were the sole and direct creations of capitalist 'penetration'. The creation of the new bourgeoisie in Damascus involved economic transformation and changes in the social structure.

\section{STUdy Aims AND MethodS}

This study aims to comprehend how authoritarian power reflects control, economic profit classes and power dispute by tracking its urban and architectural traces in Cairo. Discovering authoritarian powers in different time frames aims at exploring their shifting forms and meanings. 
Cairo will be examined for architectural and urban traces of authoritarian power during several eras. The first era during the indigenous urbanisation processes (before 1800). Then during the $19^{\text {th }}$ and the first half of the $20^{\text {th }}$ centuries (1805-1950), exogenous urbanisation was introduced. The last era will be after 1960, in which the Egyptian authorities practised topdown urbanism on a large-scale. Describing and synthesising authoritarian top-down projects in relationship to forces or players in action should explain their symbolic meanings.

\section{HISTORIC CAIRO (BEFOR 1800)}

The urban power networks of historic Cairo took three significant levels; the political ruling class, the community elites' intermediate level as political proxies, and the residents and working forces (Ghazaleh, 2013, 2005, 1999; Hanna, 2011). The three levels created two urban territories in the city. The first level created an authoritarian public urban territory at the citadel area, and the second level dominated the city public roads (major and minor open-end roads) (Saad, 2018, 2007), creating a significant area of the city public territory. The third level created a secondary urban territory within the residential entities (Raymond, 2001; Saad, 2017b; Saad and Eysa, 2004). The two urban territories promoted geometric irregularity in various degrees, from the highly irregular in the secondary territory to low and very low in the public territory and the citadel area (Saad, 2017b, 2017b, 2007; Saad and Eysa, 2004) (Figures 1, 2).

Historic Cairo ruling classes (the Mamluks) were fond of multifunctional architecture, adapting a celebrative visual impact (Mostafa, 2006; Saad, 2018). Authoritarian structures were mostly built by high-ranking politicians such as a Sultan, a Caliph or an army commander. Architecture can be seen as the means of protecting their private wealth or engraving their marks in history as charitable persons (Rabbat, 2010). Nevertheless, the urban city growth mechanism embedded most of the celebrative authoritarian structures within the physical context and degraded their visual impacts (Saad, 2019a, 2020a) (Figures 3). The city citadel area was a place for authoritarian power representation thanks to its spectacular, celebrative architecture, vast open area and spaces. Within this limited area, rulers and military personals assumed their control (Saad, 2018, 2017b) (see Figure 2). El-Azhar Mosque was a clear exception in authoritarian architecture. It represents the highest reference in Egypt's Islamic hierarchy but shows the most intimate visual impact among other traditional authoritarian mosques in Cairo.

Historic Cairo communities practised their right to assert the order of their urban setting or 'the ontological freedom' (Foucault, 1994). The development of each urban territoriality meant what their users saw as workable (Saad, 2019a), and little attention was given to any third party concerning its development (Mitchell, 1991). Relating urban rights to responsibilities (Hakim, 2010), safety and public services were ensured by the community members and groups (Ebrahim, 1992). Within the Cairene public territory, merchants shared such responsibility with the local authorities (Raymond, 2002). The city citadel area demonstrated an explicit exception for historic Cairo, in which the city rulers dominated and imposed their socio-political powers freely.

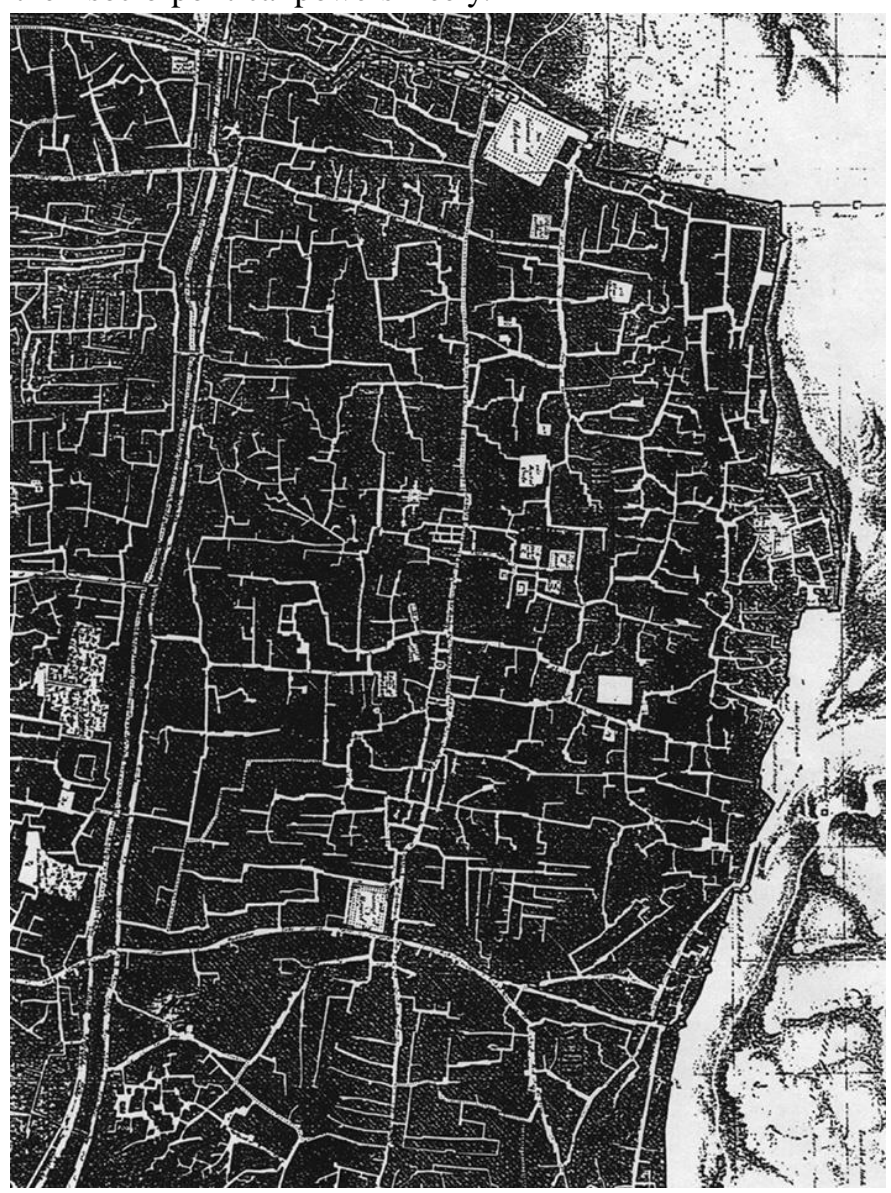

Figure 1. Historic Cairo street network; Secondary and public territories, The French Government, (1818).

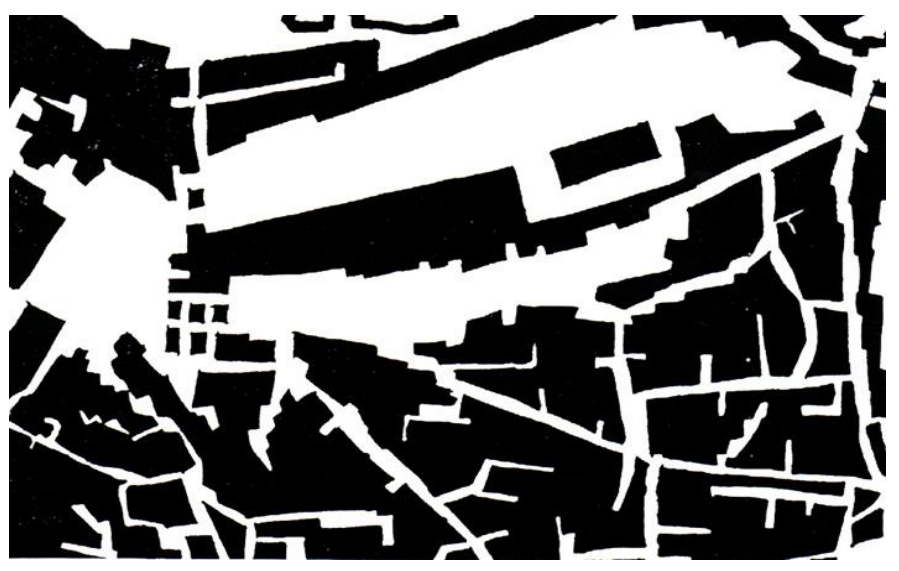

Figure 2. The authoritarian public territory at Cairo Citadel, 1800, the author. 

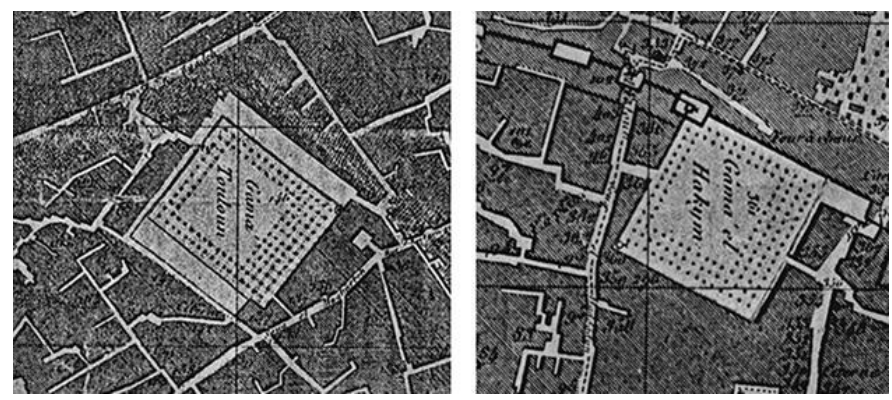

Figure 3. Ibn Tulun and Hakim Mosques totally imbedded in their physical context in 1800, The French Government, (1818).

\section{The $19^{\mathrm{TH}}$ Century CAIRo (1805-1900)}

By the beginning of the $19^{\text {th }}$ Century, an exogenous architectural identity was introduced. By ending all political and military disputes in his favour, Mohammed Ali Pasha (1805-1849) started a series of military and administrative changes (Çelik, 1992). He instituted several social and economic public facilities (Sayyid-Marsot, 1984, p. 1), ensuring power and political control for his dynasty (Fahmy, 2016). During the first decades of the $19^{\text {th }}$ Century, authoritarian architectural achievements were royal luxury palaces, an Ottoman-style spectacular mosque and a regional road. The Ottoman-style mosque was constructed on an elevated plateau in the city citadel, overlooking the historic Cairo. An Acropolislike Ottoman religious structure symbolises the Pasha's power and ethnic standpoint (Rabbat, 2010) (Figure 4). The regional road was constructed to connect the city with Mohammed Ali's summer royal palace in Shobra, northern Cairo (Figure 5). The Qanater dame northern Cairo and the regional road can be seen as authoritarian projects aiming at reinforcing the Pasha's wealth and political prestige (Fahmy, 2016).

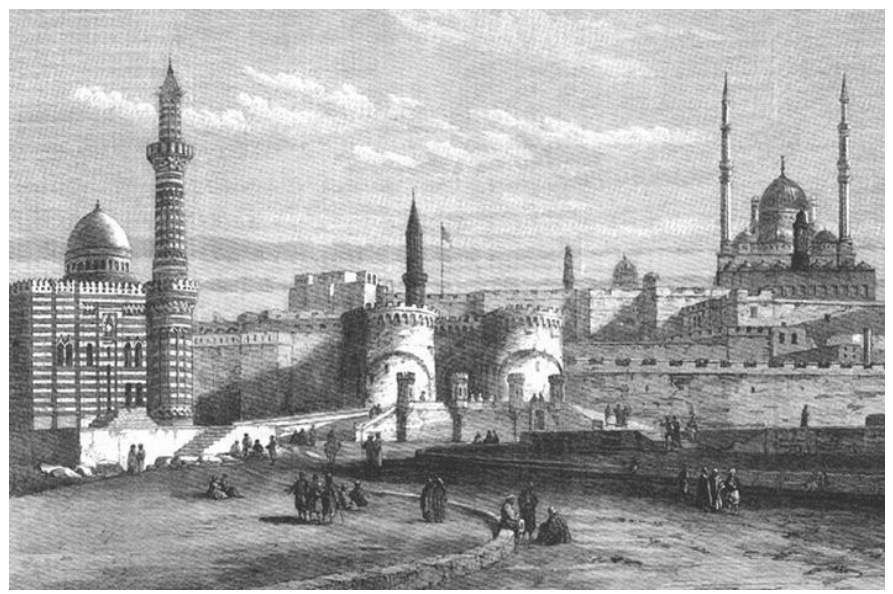

Figure 4. Mohammed Ali's Mosque; An authoritarian acropolis, 1800, The French Government, (1818).

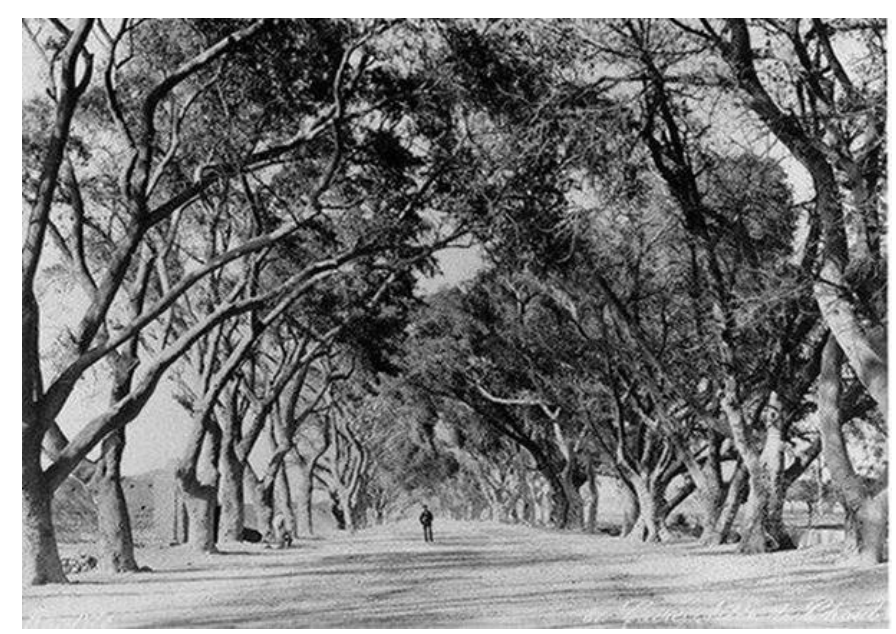

Figure 5. Shobra road around the end of the $19^{\text {th }}$ Century, private collection.

Cairo witnessed its first significant authoritarian top-down urban intervention in 1846 during Mohammed Ali Pasha's reign (1805-1847). He completed the French percée in three years; $\mathrm{el}$ Seka el-Gedida (or the new way); an axial straight street from Cairo's west to the east side. Small-scale urban projects were created during the reign of his grandson Abas Helmy Pasha (1849-1854), such as el-Abassiya (1849) and el-Helmiya (1851) western of historic Cairo (Saad, 2020b, pp. 118-119). Those urban projects should be considered land-sub-divisions among the ruling class's selective members, more than actual urban developments. However, Cairo had to wait till his grandson Ismail Pasha came to power (1863-1879) and was appointed Khedive to experience its massive medium-scale urban interventions and transformations.

Medium-scale urban projects were practised in Cairo during Ismail Pasha's reign in an area exciding the traditional city area. Ismail Pasha constructed a new extension after the French Renascences' urban rules (known today as the CBD or the Khediven Cairo). Pierre Grand Beck, one of Haussmann's senior road engineers, was appointed to realise Ismail Pasha's dreams in creating a French Cairo. Around 12 significant Meydans were connected with wide axial roads and percées and the Meydans adopted regular and primary shapes such as the circle, square and rectangle (Figure 6). Within one year recreational French-styled gardens, an artificial extension and transforming a significant river island into a geometric shape, vast open areas, royal palaces, and royal cultural facilities were constructed (Saad, 2019b). Pierre Grand Beck developed Haussmann's roads spatial articulation by dealing with each street as one design entity and unifying the visual appearance of the buildings façades. It is unclear whether such visual unity was encouraged by the state political and economic elites or by Pierre himself on the drawing board. By the end of the $19^{\text {th }}$ Century, the authorities' domination of Cairo urbanism created 
a new dilemma; who owns does not control, and controls do not own or uses (Akbar, 1988).

\section{MODERn CAIRO (1900-2020)}

After a slight pause during the first half of the $20^{\text {th }}$ Century, the tendency for creating medium- and large-scale architectural and urban projects immersed again with Nasser's reign (19601970). Obsessed with 'modernity', Nasser imitated the western model of urbanisation 'as the ultimate reference' (Saad, 2020c). However, the economic recession of the 1960s limited Nasser's ambition for urban development. During the Nasser era, several iconic architectural projects were created, such as the Cairo Tower, the Arab League Headquarter, the Arab Radio and Television central building and the Socialist Union Headquarters. Medium- and large-scale urban projects such as Sahafeyyen (the journalists' quarter), Mohandseen (the engineers' quarter) and Medinet Nasr (the city of victory) emerged. Industrial areas, as well as social low-income housing, were constructed. Despite Nasser political Arabism slogan, none of his authoritarian projects promoted local Arabic identity (Saad, 2020c) (Figure 7, 8).

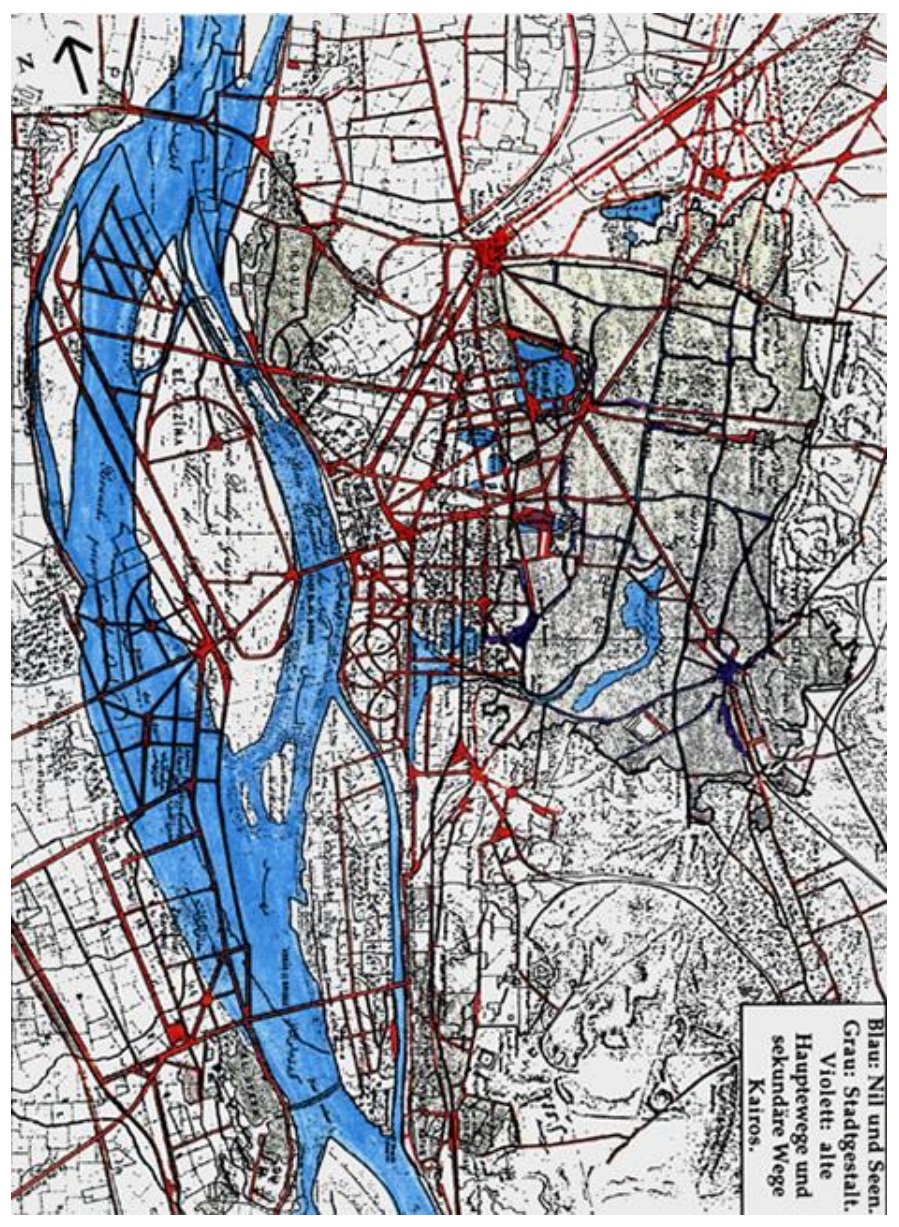

Figure 6. Ismail Pasha's urban interventions in Cairo, 1870s, Saad, S. (1994).
By defining itself as the provider of low- and middleincome classes (El-Shakry, 2006, p. 84), Nasser's revolutionary state monopolised Cairo urban development. Authoritarian new forces stormed Cairo, and against its Socialist slogan, the colonial's authoritarian power representation trend continued.

By defining itself as the provider of low- and middleincome classes (El-Shakry, 2006, p. 84), Nasser's revolutionary state monopolised Cairo urban development. Authoritarian new forces stormed Cairo, and against its Socialist slogan, the colonial's authoritarian power representation trend continued.

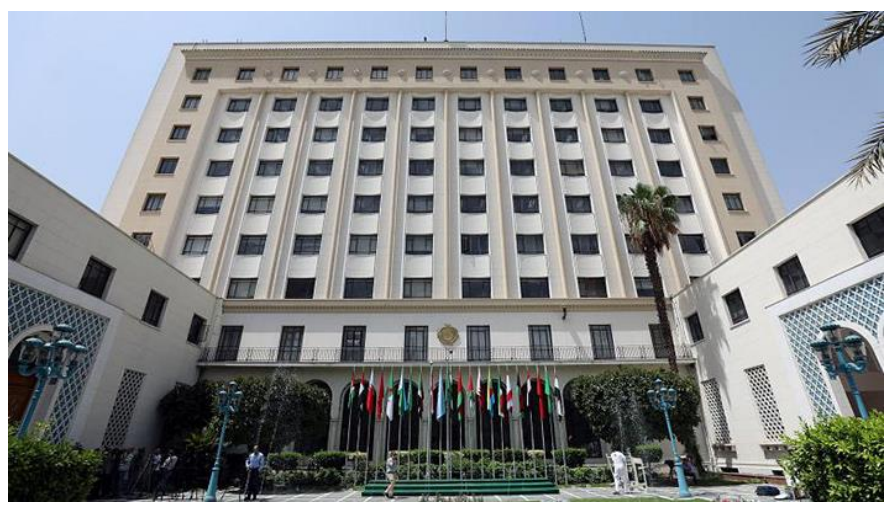

Figure 7. The Arab League Headquarters in Cairo, the author.

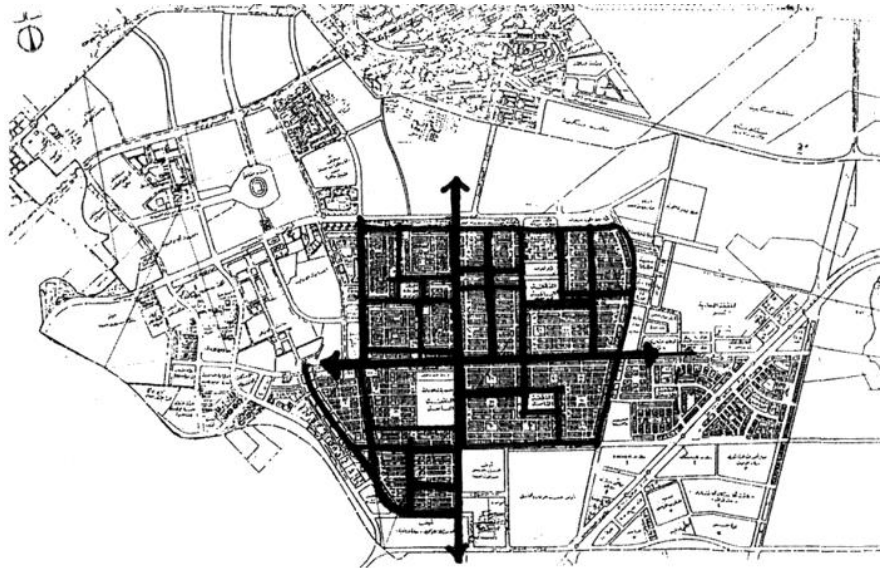

Figure 8. Naser City Master Plan, Saad, S. (2020c).

The powerful display of iconic 'buildings, squares, and streets was adopted to signify authority, supremacy, and discipline' (Selim, 2016, p. 194). Nevertheless, economic depression minimised Nasser urban development, keeping a distance behind Ismail Pasha's projects. The first Cairo master plan (the 1960s) suggested the construction of satellite towns to become 'relief poles' for Cairo overpopulation (Sims, 2000, p. 17). While Omnia (El-Shakry, 2006, p. 74) emphasised the social welfare characterised the period of the 1930s to the 1960s, changes in the urban territoriality, structure and hierarchy after 1970 reinforced social segregation.

During Sadat's tenure (1970-1980), desert towns and cities became an authoritarian urban fashion. He intended to relocate the Egyptian capital to a new city, Medinet el-Sadat (the Sadat 


\section{International Journal of Engineering Applied Sciences and Technology, 2021 \\ Vol. 5, Issue 11, ISSN No. 2455-2143, Pages 83-95 \\ Published Online March 2021 in IJEAST (http://www.ijeast.com)}

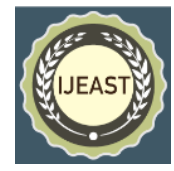

city). His death, however, stopped the displacement of governmental institutions, and in a few years, the project was neglected. Mubarak (1980-2011) followed Sadat's footsteps in his urban fashion but promoted large- and mega-scale projects. Mubarak's relatives, related capitalist and investors, gained vast development areas at low prices. In the 1980s the IAURIF (Institut d'Aménagement et d'Urbanisme de la Région d'Ile-deFrance) presented a new master plan for Cairo. The master plan suggested constructing ten urban settlements (dormitories or towns) in the city's eastern arc. The settlements aimed at being relief poles for informal housing homesteaders in Cairo, but such aim was not implemented, and the settlements were transformed to accommodate upper-income classes. (IAURIF and GOPP, 1991). Constructing gated communities, desert dormitories intended to attract capitals and foreign investments (Saad, 2020d).

After 2013 the Pretorian state monopolised the urban development in a top-down process and redirected it to the SCAF (Supreme Council of Armed Forces) controlled lands. Constructing the New Administrative Capital presents an urban motivation for the high-income classes to abandon Cairo. The vital fundamental design concept of the New Administrative Capital was to create a grand 'monumental' city (Ali, 2019) (Figure 9). Repeating the last decades' failures leave little doubt about the authorities intentions in solving the urban problems of marginalised classes. The marginalised classes' housing development is neither profitable nor prestigious, but constructing new desert towns and cities attracts private investors willing to share their profits with the authorities.

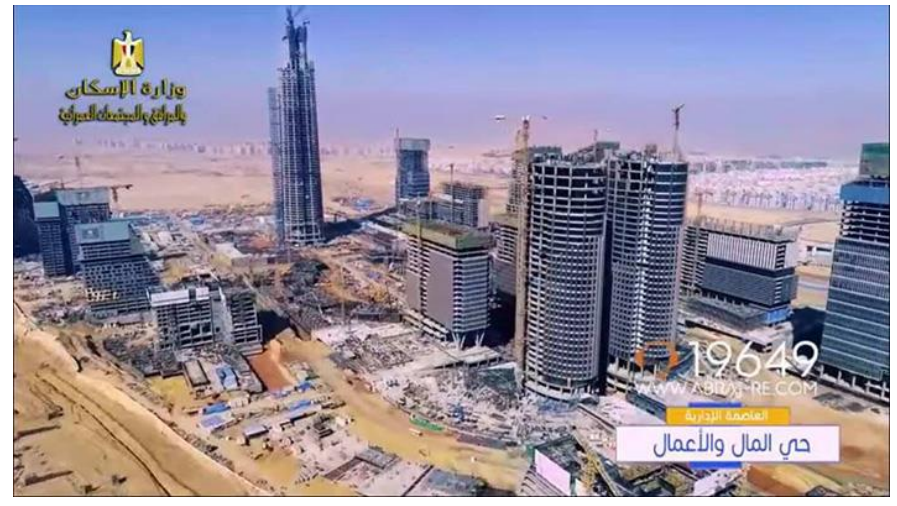

Figure 9. The New Administrative Capital of Egypt, 2021, Ministry of Housing, Utilities and Urban Communities (2021).

\section{CAIRO; AN ARENA FOR POWER DisPute?}

Allen argued that power is a general facility for enabling thing to happen (Allen, 2010), and Cairo history teaches us that power was also practised for gaining a prominent position. In order to occupy a significant and prestigious node in the power network, control is vital. Thus practising control minimise the chances of losing one's power. Since the public space offers a stage/forum - for political representation, display and action (Varna and Tiesdell, 2010, p. 579), the Egyptian authorities aimed at controlling the city's public domain by monopolising its production. Building laws and regulations were created to strengthen authoritarian power and control. Top-down authoritarian urban investments replaced the bottom-up urbanism; the public right to assert the order of their built environment became a form of chaotic activity (Ashwa'ayat in Arabic). During Nasser tenure, asserting control over the 'urban' was conceived as an aim of the Egyptian authorities to impose their political power and discipline. Creating a paradoxical association (Beauregard, 2011, p. 470) between the state actions and political slogans (Saad, 2020c). During Nasser's reign, planning Cairo was an effort to modernise the city and impose control over the community (Bale and Blake, 2017). The 1960s Cairo master plan was not implemented due to Nasser's regime's fear of losing control over Egypt's working force.

The tendency for representing the rulers' authoritarian power can be traced along with Cairo history. Such representation took various forms and levels according to each era. In historic Cairo, the authoritarian urban power representation was mainly limited within the city citadel area and on the architectural level at major arterial roads (Figures 10, 11). Nevertheless, the public struggle for their ontological freedom was reflected upon authoritarian buildings' physical context and urban spaces' geometric form (Saad, 2017b). Their celebrative impact was contained, and power representation was degraded. The public ontological freedom created an overwhelming physical context integrating authoritarian structure within the city ensemble (Saad, 2018). The power network's intermediate level was a buffer protecting the public's interests and balancing higher and lower power levels (Ghazaleh, 2013, 2005).

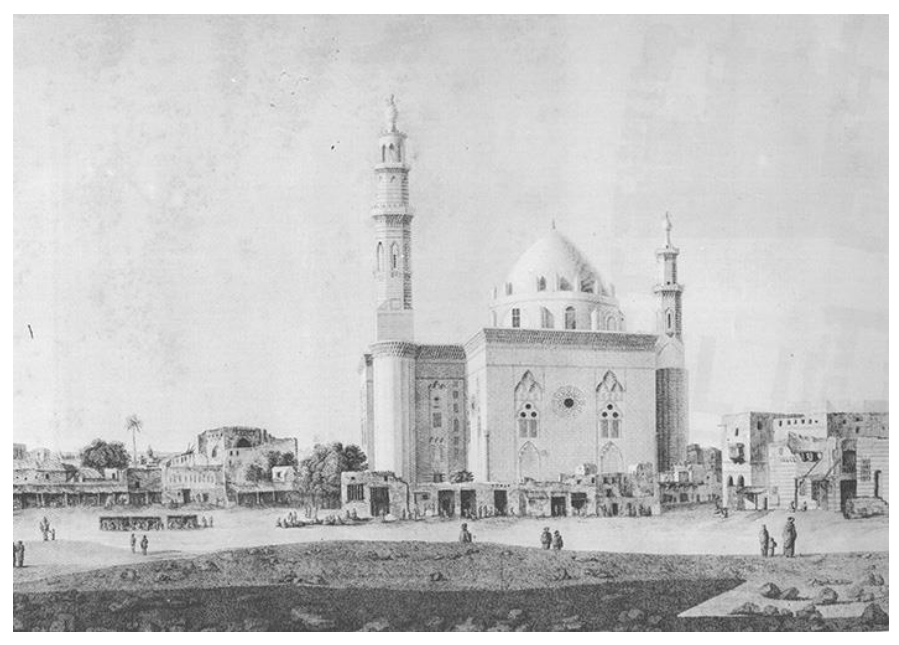

Figure 10. Sultan Hassen Mosque; An authoritarian power representation, The French Government, (1818).

While 'planned districts and model housing were territorial mechanisms designed to represent the legitimacy' of colonialism (Selim, 2016, p. 183), they were perfectly replicated by the local Egyptian authorities in the $19^{\text {th }}$ and $20^{\text {th }}$ centuries (Badie, 2000; Mitchell, 1991; Saad, 2019b). 
Enframing authoritarian buildings, representing geometric axial streets and Meydans, was a significant physical reflection of the authoritarian power representation in modern Cairo (Figure 12). The urban external appearances became a primary authoritarian interest (Saad, 2019b). The Egyptian authorities replaced the colonial forces as proxies by controlling the city, adopting a top-down urban process and considering the marginalised classes in their informal housing as the 'others' (Saad, 2020d).

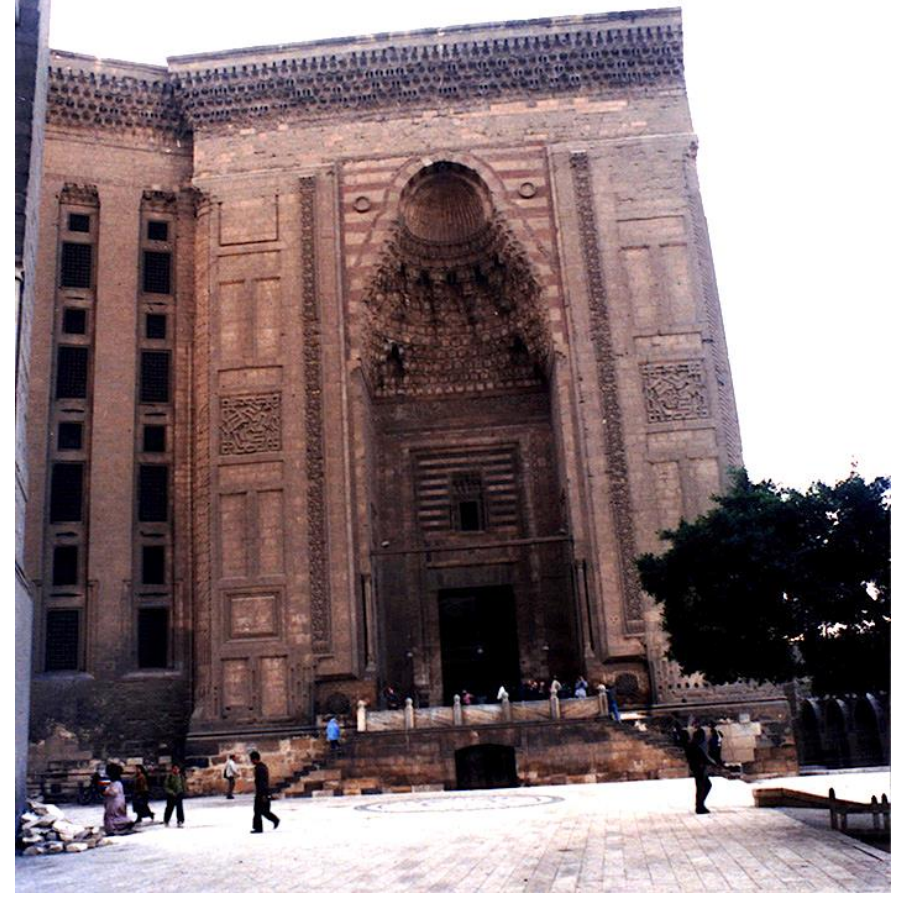

Figure 11. Sultan Hassen Mosque's celebrative entrance, the author.

Egyptian authorities' failure in solving Cairo problems during the $20^{\text {th }}$ Century cannot be considered an unconscious act created by human trail and error. Transforming new desert settlements to accommodate high-income classes or to be absorbed into the preexisting military and police housing programs -developed without reference to the original scheme (IAURIF and GOPP, 1991), seems to be a conscious decision.

Before the $19^{\text {th }}$ centuries, power dispute succeeded in cornering the ruling class power practice within a limited area and mainly on the architectural level. Ismail Pasha promoted the medium-scale urban projects on a wide range in the $1870 \mathrm{~s}$ to disempower the public and empower the royal family, ruling classes and ending the Egyptian community's urban involvement and collaboration. Wide straight roads and percées, authoritarian buildings as vistas, celebrative and spectacular urbanisation became the recent urban power dispute's physical end-product. Authoritarian architecture and urban projects represent what Castells (Castells, 1977, p. 378)considered the power in players' acts. The exogenous urban identity and urban processes were decision-makers traces of the power level in the $19^{\text {th }}$ Century. Imposing a third party's control over the city can be seen as a result of two integrated objectives; eliminating the public power that lies in the streets, as Castell argued, and ending the public ontological freedom. Both of those objectives are implemented to stop challenging the authorities, 'the rich and powerful' (Uitermark et al., 2012).

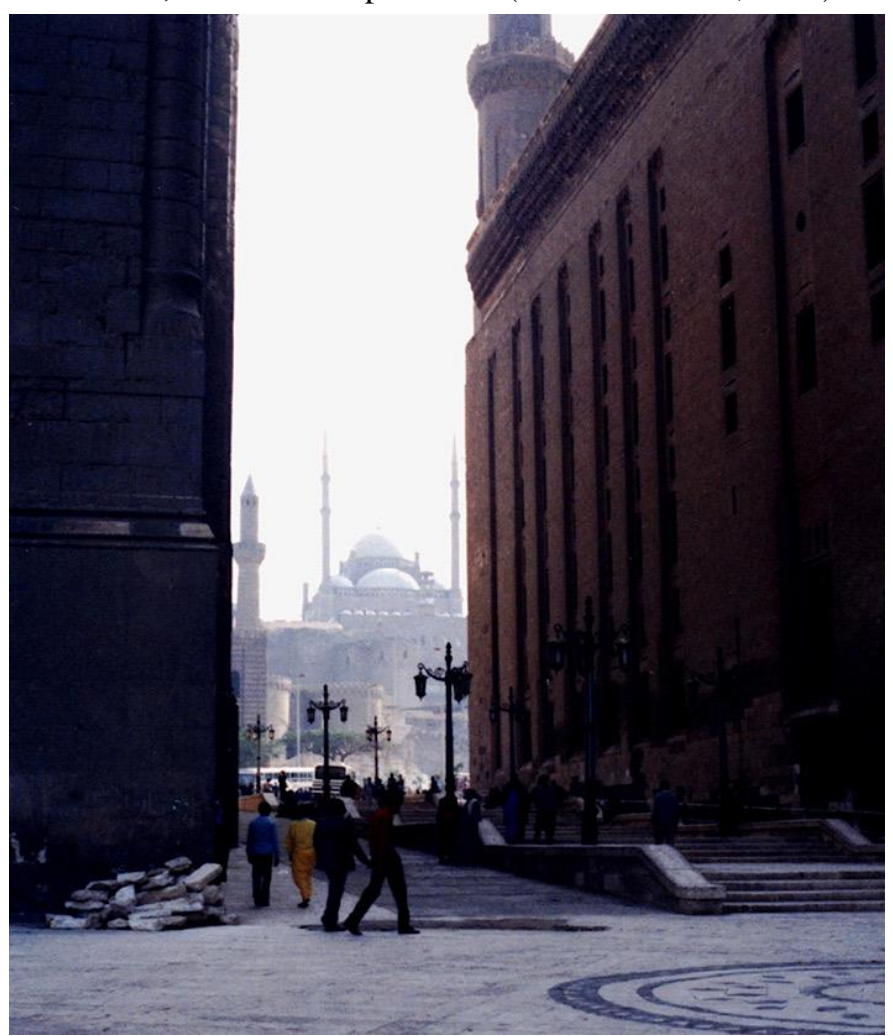

Figure 12. Enframing Mohammed Ali Mosque, the author.

Nasser promoted medium-scale architectural and urban projects, empowering his ruling classes. Sadat and Mubarak took the authoritarian urbanisation further by constructing large-scale urban projects and dessert settlements. While Sadat's regime empowered the military and encouraged the private business people simultaneously, Mubarak attempted to minimise the SCAF power using the ruling class's entrepreneurs. The Pretorian state took the authoritarian power to a higher level by monopolising the mega-scale urban investments, and the SCAF gained the governance power position.

The SCAF attitude of conceiving lands can be traced back to Nasser and Sadat to secure the armed forces' political support. Nevertheless, later, the Egyptian Defense Ministry developed its real-estate investment plans for much of East Cairo. Mubarak's struggle to construct new desert towns on military-controlled land was interpreted by Dorman (Dorman, 2013) as a reflection of the power dispute between his business people and the military in gaining control over the urban investment. Egyptian economic and political elites proved their ability in imposing their power on the planning technocrats. 
Their powers redirected the IAURIF master plan in their favour, and their power practice found full collaboration from the authorities due to their coalition. The Pretorian state urban investment was not limited to housing projects but exceeded other commercials, health and educational facilities. Announcing the construction of four new prestigious universities offering 'the highest quality of academic education' for those who can afford their tuition fees was celebrated by the Pretorian officials (El-Wazier, 2020) as the physical application of the SCAF power monopoly.

During the $19^{\text {th }}$ Century, the new socio-economic and cultural elites' political domination created a clear shift in Cairo's power network. In the $20^{\text {th }}$ Century, the urban governance network sustained its central colonial structure but shifted its players. Nasser's military regime backed by the cultural, economic and political elites dominated the network. Globalisation might have transformed the architectural appearance and Cairo urbanism (Bale and Blake, 2017), but authoritarian power representation sustained its colonial core. Whether the $19^{\text {th }}$ Century Cairo urban's geometric regularity was adopted to impose sociocultural isolation or its unfamiliar exogenous urbanism created such isolation, is not clear. However, Cairo Haussmannisation resulted in imposing an authoritarian top-down urban process as an urban default. The contrast between traditional irregularity and modern Cairo geometric regularity can be seen as the reflection of power dispute between the traditional and the Western urban quality in terms of ontological freedom and authoritarian control. The $19^{\text {th }}$ Century Cairo axial streets and geometrically regular Meydans do not reflect sociocultural, economic, and political forces only but reflect the winning party in the power dispute.

Consistent with authoritarian high modernism, state planners have thought to contain Cairo's growth and redirect it top-down. The planning schemes in Cairo aimed at controlling Cairo's urbanisation top-down, but informal housing is seen by Dorman (2013) as a way of creating urbanisation from below. Whether informal housing represents the authority's failure in providing sufficient and adequate low-income housing (Hamdan, 1993), or they represent socio-economic segregation (Saad, 2020d), the need to stop the marginalised classes' right to assert the order of their built environment is considered vital to modern Egyptian authorities. As formal urbanism is considered a form of compliance to the authorities, informal urbanism demonstrates the authority failure of imposing order.

Cairo urbanism shows us that the elite has functioned as a coalition of dependent interests around the rulers, including the military, dependent on state-created rents and opportunities (Adly, 2012). The Pretorian state reshaped the urban power network again, and the military officials dominated it but kept its colonial character; autocratic, top-down urban process, megscale vehicle-oriented projects and abandoning the 'others'. The statement of 'the state ownerships' -created during the Monarchy- is still in use in contemporary Egypt, replacing the concept of public property and reflecting the hidden meaning of authoritarian power in the collective memory. Whether such power shift, structure and network-level were mandatory to bring Egypt into 'the modern ages' (Ufford, 2007) or not, the outcome was disempowering the public, illegalising the bottom-up urban process and establishing the top-down autocratic urban process.

\section{CAIRO, A CITY FOR PROFIT?}

Before the end of the $18^{\text {th }}$ Century, the small- and microeconomy dominated Cairo economic power network. The urban development was mainly created due to cumulative architectural individual activities. Few ruling class's members invested in large areas by constructing basic urban facilities and renting the vacant area. The rented vacant area was developed by individual large families or groups of people. Each family or group of people controlled their sub-divided area in a deliberative bottom-up process by respective general religious rules and Urf (or building customs) (Hakim, 2001). By the time Mohammed Ali came to political power, he had monopolised the construction economy, tool and materials. His relatives were given access to authoritarian urban decisions, architectural renovations and development in Cairo on a wide scale. Mohammed Ali's family and ruling class took advantage of such a monopoly in reinforcing their network's economic position.

By Promoting Renaissance urbanisation in the $19^{\text {th }}$ Century Cairo, the local small- and micro-economic forces were eliminated from taking a significant role in the city urbanisation. A shift in the urban wealth distribution from the micro-economy to large economic enterprises strengthened the ruling class's economic force (Saad, 2019b). Medium-scale urban projects required big financial establishments and foreign banks, presenting new players in urban power networks. Introducing big investors, technocrats, politicians, and members from the ruling class brought the urban development process to the highest profit level.

After a slight pause during Nasser's tenure, private urban investments dominated the urban power network. Businesses people related to Sadat and Mubarak enjoyed privileges in accessing development land at marginalised prices. During the last decades of Mubarak's tenure, urban investors became among the wealthiest Egyptian businesses people. Sadat and Mubarak took advantage of constructing new desert settlements to attract foreign aids and investments. The military coup of 2013 shifted the Egyptian economic power network's players in favour of the SCAF generals and the army officers.

Confiscating previous ruling classes' assets and wealth was repeatedly practised from the $18^{\text {th }}$ Century until the $21^{\text {st }}$ Century by the new players in Egypt's political power network. After restructuring the economic power network by Mohammed Ali in favour of his ruling class in the 1820 s, the network kept changing its players along with Cairo history but kept its core structure; a ruler-businesses-people-alliance. By the time Mubarak became president, eight out of Egypt's top ten wealthiest businesspeople were real estate investors related to 


\section{International Journal of Engineering Applied Sciences and Technology, 2021 \\ Vol. 5, Issue 11, ISSN No. 2455-2143, Pages 83-95 \\ Published Online March 2021 in IJEAST (http://www.ijeast.com)}

the ruling class. Real estate investments presented around $40 \%$ of the Egyptian national income (Central Agency for Public Mobilization and Statistics, 2017).

The Pretorian state became involved in mega-scale urban investments through the Defence Ministry's land bank. Developing such lands came in joint venture transactions for high-profit (Abaza, 2016, p. 113). Several new desert towns, universities, and new capital are examples of the Pretorian state economic role. The urban investments' high economic profit attracted the Pretorian state in monopolising vast desert areas around Cairo and other cities. The New Administrative Capital became the cherry on top of its urban economic activities with its spectacular and celebrative design. Despite that it is officially considered an administrative city, it is used to attract real estate investments in housing, education and services in partnership with the Defence Ministry. The SCAF became involved in real estate development as private investors and mediators (Dorman, 2013; Sims, 2011). To create the desert property boom, the failure of contemporary Cairo planning schemes was essential. Desert development is best understood as an edifice project and exercise in elite urbanism rather than a practical solution to the problems it was nominally intended to address (Dorman, 2013). In contradiction to what Bernner, Marcuse and Mayer (Bernner et al., 2012) suggested in their book 'Cities for people, not for profit', contemporary Cairo became a city for pure capitalist high-profit. Urban decisions that affect ordinary Egyptians' everyday lives are taken topdown by political, business people, administrative authorities, or technocrats favouring the wealthy. The economy is significant without a doubt, but only directing it favouring the rich and powerful classes is unjust.

As Routledge (Routledge, 2010, p. 1166) noticed, the authorities' decision-making power shifted away from urban citizens towards the corporate sector, creating socio-economic opportunities for the Egyptian high-income classes. The Pretorian monopoly of the private and public property strengthened such structure and alliance; the urban setting became 'the supreme object of governance' (El-Shakry, 2006, p. 75). Informal micro-economy presents marginalised threat to the economic elites, because of its low profit margin. But distinguish informal areas presenting potential profits became arenas for classes disputes. The last decade, however, demonstrated the economic elites' triumph in those disputes. Informal housing was met by the Egyptian cultural and economic elites with aggression. The Egyptian media launched massive campaigns against informal housing favouring the Egyptian elites, but their residents faced such aggression by constructing more informal areas.

\section{CAIRO; AN ARENA FOR Class Dispute?}

The relationship between authoritarian urban development and the shift in the ruling class's sociocultural and economic status can be noticed in Cairo modern history. Cairo urbanisation was used during the Mohammed Ali dynasty for strengthening the ruling classes' sociocultural position. The symbolic meaning of the exogenous urban elements created in Grand Beck's plans (the 1870s) reflected the new actors and forces in action. The cultural Meydan at el-Azbakeyia reflects the westernised new cultural class. The political Meydan at Abydien reflects the new powerful Monarchy and its 'civilised face', and the communication and industrial Meydan Bab elHadid reflects the new economic force's pivotal role. New spectacular and celebrative percées and axial streets symbolised the new Westernised sociocultural classes (Saad, 2019b) (Figures 13, 14, 15).

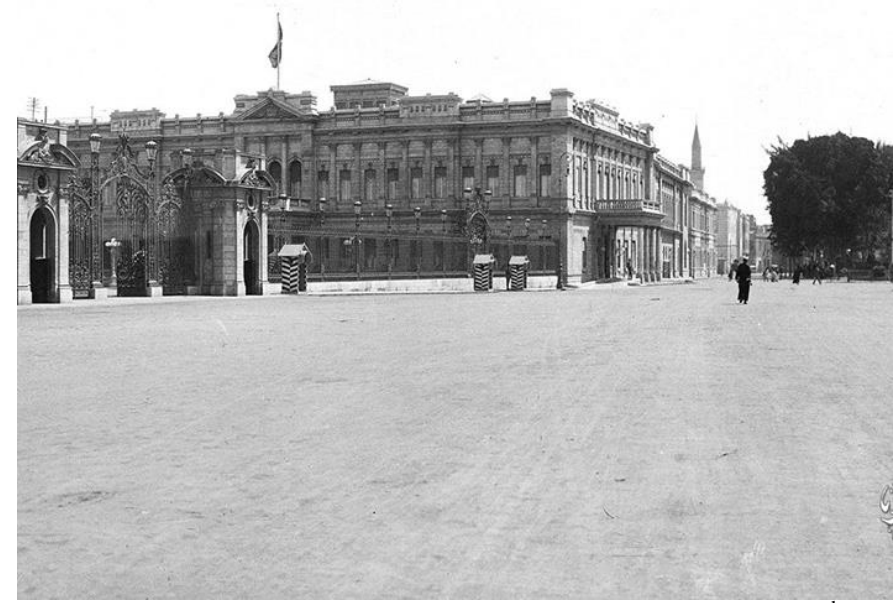

Figure 13. Meydan Abedyen, around the beginning of the $20^{\text {th }}$ Century; Political representation, private collection.

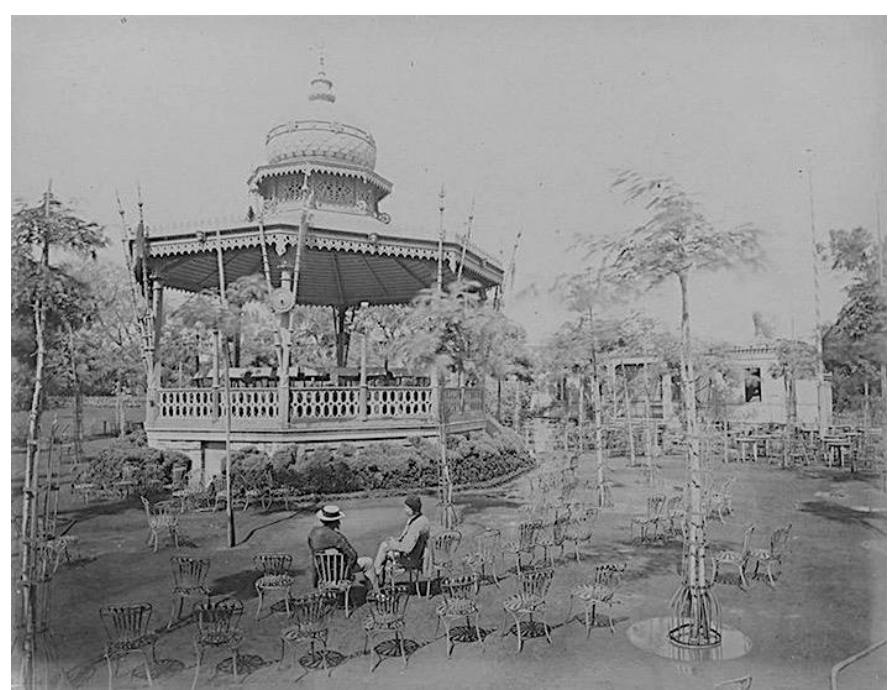

Figure 14. The music shack at Azbakeya garden around the bingeing of the $20^{\text {th }}$ Century; A cultural representation, private collection.

Drawing on Badie's argument, the political support of the new westernised classes created an 'owner-client' (Badie, 2000) relationship between the state and community members in 
Cairo in their search for better life quality. However, marginalised classes lost a lot of their sociocultural positions. Individuals may privilege the motivating power of relationships within their particular place-bundles (Pierce et al., 2010, p. 58), but, in contrast to marginalised classes, Egyptian elites joined authoritarian place-bundles, through which they reinforced the transformation of Cairo planning schemes into top-down urban processes. Their socio-economic position gave them the ability to move between various power nodes.

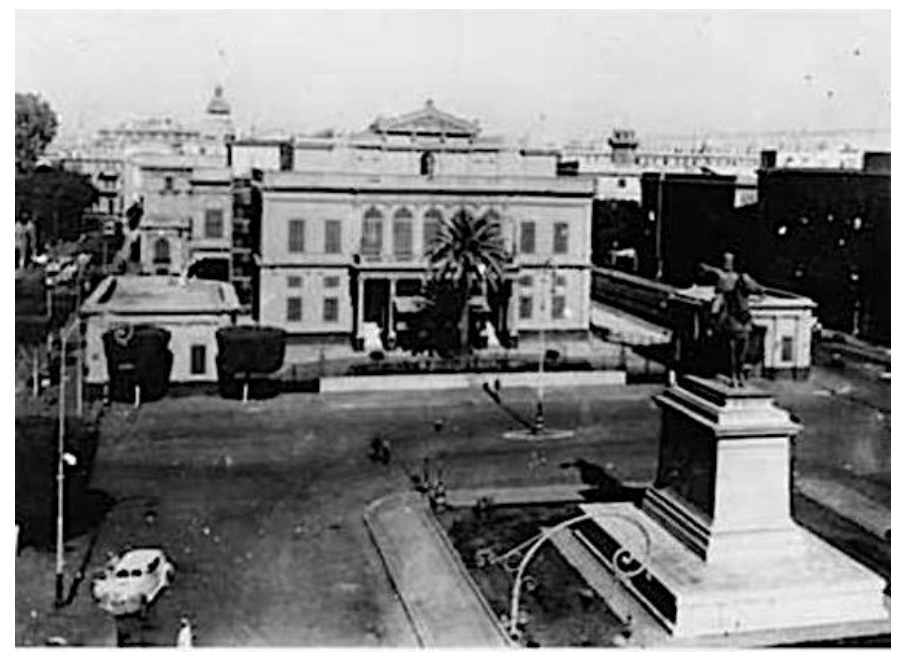

Figure 15. Opera Square; a cultural representation around the bingeing of the $20^{\text {th }}$ Century private collection.

As a result of social neglect and inequality (Saad, 2020d), two-third of the Cairo population became outside the state's authoritarian power (Sims, 2011). Following Barnesmoore (Barnesmoore, 2018) argument, informal housing can be seen as the marginalised classes' hidden and peaceful protest against the authoritarian neglect. The few authoritarian attempt for upgrading informal housing ended by promoting what Deboulet (Deboulet, 2009) called the 'dictatorship of the straight-line' as a form of authoritarian discipline.

The change in Cairo's spatial settings since the beginning of the $20^{\text {th }}$ Century was a 'struggle over the public sphere' (Singerman and Amar, 2006, p. 36). The tension between the Egyptian elites -supporting the state top-down urban processand the marginalised classes' right in balancing the state urban and social neglect became overwhelming. Marginalised classes in Cairo are struggling for their right to having decent accommodation creating informal areas. It is how the 'city act as a crucial site for the production of resistance identities and practices' (Routledge, 2010, p. 1170). Despite the increasing sociocultural elites' media pressure on informal housing residents, informal areas kept spreading and attracting more residents.

\section{CAIRO's SYNOPTIC INFRASTRUCTURE AND POLITICAL PROPAGANDA}

Introducing the most prominent, tallest and most spectacular urban and architectural projects reflects more than just profit, power, and classes dispute in modern Cairo. In June 1867, Ismail Pasha travelled to Paris to attend the Egyptian Pavilion opening in the International Industrial Exposition (Mubarak, 1970). The French authorities organised Parisian spectacular visits for their prominent guests, and Panerai (Panerai et al., 2005) described Ismail Pasha's impression during his visits as 'amazed and conquered.' Ismail Pasha's urban interventions aimed to invest the ruling class's cultural, social and political forces. He took advantage of his grandfather's 'synoptic infrastructure' and imposed a westernised elites 'synoptic viewing' (both terms are cited from (Coleman, 2018)). Mohammed Ali Pasha established the synoptic infrastructure in Cairo, and Ismail Pasha developed it further. The creation of new socio-economic and cultural classes during the $19^{\text {th }}$ Century, created a synoptic infrastructure that succeeded in demonising the marginalised classes' role in urban development and illegalising their bottom-up urban process.

Within one year (1869-1870), Ismail Pasha's dreams for Europeanizing Cairo, was ready to impress his prominent visitors. Meydans, significant authoritarian structures and gardens were adopted as visual vistas for celebrative roads (Figure 16). Kirjakka (Kirjakka, 2010, p. 5) argued that the street was considered a monumental whole and not just a space for communication according to the Renaissance urban concept. The French Renaissance's theatrical and spectacular urbanism (Cruceru, 2011) invaded the city Image. Satisfied with Cairo's urban 'development', Ismail Pasha said to European ambassadors: 'for thirty years, the European influence has transformed Egypt, now [...] we are civilised' (Çelik, 1992, p. 13). By the end of the $19^{\text {th }}$ Century, a silent culture of shame (Çelik, 1992; Mitchell, 1991) became an overwhelming attitude, implying that the traditional built environment represents backwardness and is a reminder of messy urban life (Hakim, 2001, p. 88). The local urban process was forgotten, and the ruling classes imposed their synoptic viewing.

By the time Nasser came to power, the synoptic infrastructure had succeeded in establishing an influential 'synoptic viewing'. Two centuries of authoritarian control and disciplinary education, cultural activities and media propaganda succeeded in creating synoptic viewing by imposing the ruling elites' perspective on the majorities. Disciplinary practice replaced the traditional bottom-up urban process with the authoritarian top-down process on both the cognitive and physical dimensions. Living in an informal area became very shameful. Motivated by celebrative and spectacular slogans, Nasser's urban developments were considered cities or towns (medina in Arabic). Ironically, Medinet Nasr authority, for example, is officially called: 'Ha'y Medinet Nasr' (The District of Nasr City's Authority).

Sadat's urbanism was not only economic but political propaganda was associated with his authoritarian medium-, 
large- and mega-scale projects. Laying the foundation stone and cutting the project's opening ribbon became a presidential routine. His large-scale urban interventions in Cairo aimed to replace different areas in the city centre with high-rise structures to reinforced his political slogan of creating 'a youthful face of Egypt' (Ghannam, 2002, p. 31).

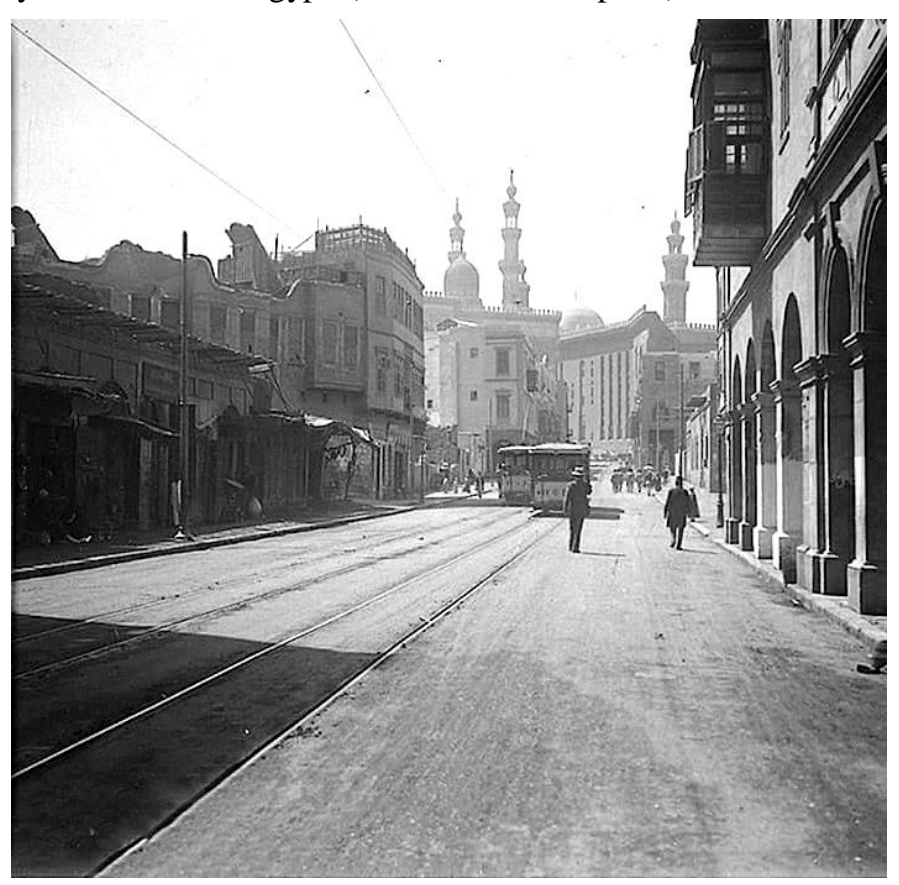

Figure 16. An axial percée around the bingeing of the $20^{\text {th }}$ Century, private collection.

This slogan was repeatedly used in different variations, from Ismail Pasha to the Pretorian state. The authoritarian's notion of creating the biggest, the tallest, the most modern, the most spectacular and the most monumental projects represents an inherited political prestige in Egypt.

Neither Sadat's nor Mubarak's failure to establish new capital and desert towns prevented the Pretorian state from making the same top-down and autocratic decision to construct the 'New Administrative Capital'. However, el-Hazlul (ElHazlul, 2010) considered a new town's creation as 'the ruler's spectacular act.' The New Administrative Capital replicates, but on a mega-scale, what Kumar (Kumar, 2017, p. 1035) considered a colonial symbol of the implied sociocultural, architectural, and political superiority' ordinary to India's British imperialism. Contemporary Egyptian authorities became very fascinated with mega-scale urban projects for their spectacular, celebrative and monumental impacts. In his book 'Colonising Egypt', Mitchell (Mitchell, 1991) argued that the western forces still colonise Egypt since the state mimics Western cultural, economic, and political systems. Barnesmoore (Barnesmoore, 2018, p. 197) argued that the fight for decolonisation, freedom and social justice 'must begin by fighting for 'ontological justice.' To face the ontological freedom's potential threat, the Egyptian authorities encourage the high-income classes and socio-political elites' engagement in privatising the urban setting.

The SCAF took advantage of the dominating synoptic viewing to monopolise civil life in Cairo. The built environment was transformed from a public product promoting social and urban justice to the supreme object of capitalist governance. Since sustainability requires good governance (UNESCO, 2005), fair negotiation, deliberation and the integration of the stakeholder's perspective, interests and ideas, as Shalaby indicated (Shalaby, n.d., p. 9), the Pretorian placemaking is far from being sustainable.

\section{Conclusions}

The authoritarian power representation shifted during the $19^{\text {th }}, 20^{\text {th }}$, and the first two decades of the $21^{\text {st }}$ centuries from the architectural level to limited urban interventions followed by the mega-urban project, cities and a monumental new capital. Monumentality is the authorities' tool for representing their power along with the history of Cairo. Gigantisms, spectacular, and celebrative projects became the authoritarian physical tool of political control and propaganda.

Cairo's authoritarian power's urban traces shifted its representation from a limited area before 1800 to controlling the city development after 1870 and monopolising large- and mega-scale urban investment after 1960.

By eliminating ontological freedom in the $19^{\text {th }}$ Century, the Egyptian authorities freely practised its top-down urban process. In the last two centuries, the state played various roles in disempowering, narrowing, and constraining Egypt's public. Nevertheless, it failed in totally disempowering the marginalised classes by being unable to stop their informal housing from spreading. Modern Cairo urban setting became an arena for classes dispute between marginalised classes in their informal area and the socio-economic and ruling classes in their formal urban settings.

Cairo urban history teaches us that the economic profit is significant, but the urban setting is used for authoritarian control, the rulers' political prestige, empowering the ruling classes, and shifting or restructuring the governance network. Layers upon layers of authoritarian control strengthened and normalised the state synoptic infrastructure and their synoptic viewing.

Authoritarian top-down urbanisation in Cairo promotes different significant objectives. Before the $19^{\text {th }}$ Century, it promoted prestige, personal identification and personal power representation on a limited scale. Ismail Pasha pointed the ruling class toward the political, economic and sociocultural profits by introducing small- and medium-scale urban projects. Nasser's top-down projects did not mainly, aimed for profit; they aimed for authoritarian political and cultural powers representations. After 1970, large-scale projects emerged as an economic profit-generating tool; Sadat and Mubarak aimed to generate wealth, attract foreign aides and investments. Other objectives were also present, such as political propaganda, 


\section{International Journal of Engineering Applied Sciences and Technology, 2021 \\ Vol. 5, Issue 11, ISSN No. 2455-2143, Pages 83-95 \\ Published Online March 2021 in IJEAST (http://www.ijeast.com)}

personal prestige and the ruling class's sociocultural empowerment. The first two decades of the $21^{\text {st }}$ Century introduced authoritarian mega-scale spectacular urban projects, car-oriented placemaking and aimed for economic profit, political propaganda and empowering the Pretorian state (Saad, 2020d).

Every power shift was associated with urban contestation in Cairo. The urban contestation shifted from the urban deliberation process to discriminate against it. The urban monopoly and domination continued but was governed by various players, introducing private real estate investors related to the rulers (1970-2011) and dominating urban investment by the SCAF after 2013. The Pretorian state practices its control over the city to generate economic profits and impose its power on civil life.

\section{REFERENCES}

1 Abaza, M. (2016). Violence, Dramaturgical Repertoires and Neoliberal Imaginaries in Cairo. Theory, Culture \&amp; Society 33, 111-135.

2 Adly, A. (2012). Mubarak (1990-2011): the state of corruption. Amman, Arab Reform Initiative. URL www.arabreform.net/sites/default/files/Mubarak_19902011_The_State_of_Corruption.pdf

3 Akbar, J. (1988). Crisis in the Built Environment: The Case of the Muslim City. Concept Media Pte Ltd., Singapore.

4 Alexander, C. (2002). The Nature of Order, Books II, Part Two. The Center for Environmental Structure, Berkeley.

5 Ali, K.H. (2019). Gated communities: Symbols of fear and status - Features - Egypt. Ahram Weekly.

6 Allen, H. (2013). Imag(in)ing Work and Urban Experience in the New Deal. Journal of Urban History 39 ,

$555-559$ https://doi.org/10.1177/0096144212467295

7 Allen, J. (2010). Powerful City Networks: More than Connections, Less than Domination and Control. Urban Stud 47, 2895-2911. https://doi.org/10.1177/0042098010377364

8 Badie, B. (2000). The Imported State: The Westernization of the Political Order. Translated by: Claudia Royal. Stanford University Press, California.

9 Bale, C., Blake, J. (2017). Greater Cairo: From Patriotism to Privatization Urbanization \& Development. URL https://www.academia.edu/35890501/Greater_Cairo_ From_Patriotism_to_Privatization_Urbanization_and _Development (accessed 3.23.20).

10 Barnesmoore, L. (2018). The Right to Assert the Order of Things in the City. CITY: analysis of urban trends, culture, theory, policy, action 22, 183-200.

11 Beauregard, R.A. (2011). Time, action, space. Vol. 32, 470-475. Urban Geography 32, 470-475.
12 Bernner, N., Marcuse, P., Mayer, M. (2012). Cities for People, Not for Profit: Critical Urban Theory and the Right to the City. Routledge, London and New York.

13 Castells, M. (1977). The Urban Question: A Marxist Approach. Edward Arnold, London.

14 Çelik, Z. (1992). Displaying the Orient. Architecture of Islam at Nineteenth-Century World's Fairs. University of California Press, Berkely, Los Angeles, Oxford.

15 Central Agency for Public Mobilization and Statistics, 2017. The National Census Periodical Report (Statistics). Cairo.

16 Coleman, R. (2018). The Synoptic City: State, "Place" and Power. Space and Culture 22, 1-15.

17 Cruceru, A. (2011). Urban form, transit space, and the public realm (Master). University of Guelph, Canada.

18 Deboulet, A. (2009). The Dictatorship of the Straight Line and the Myth of Social Disorder: Revisiting Informality Cairo, in: Singerman, Diana (Ed.) Cairo Contested: Governance, Urban Space, and Global Modernity. AUC Press, Cairo, pp. 199-234.

19 Dorman, W.J. (2013). Exclusion and Informality: The Praetorian Politics of Land Management in Cairo, Egypt. International Journal of Urban and Regional Research 37, 1584-1610. https://doi.org/10.1111/j.1468-2427.2012.01202.x

20 Ebrahim, S. (1992). El-Haya el-Egtimaia fe Madinet el-Kahira khelal el-Nisf el-Awal mi el-Qarn elTasea'a Ashar. Egyptian General Book Authority, Cairo.

21 El-Hazlul, S. (2010). El-Madina el-arabia el-islameya. Athar el-tashre'a fi el-bena'a el-omrani (The ArabicIslamic City. Impact of Religious Rules on its Built Environment). Saudi Association for Urban Sciences, Riyadh.

22 El-Shakry, O. (2006). Cairo as Capital of Socialist Revolution?, in: Singerman, Diana and Amar, Paul (Eds.) Cairo Cosmopolitan: Politics, Culture, and Urban Space in the New Globalized Middle East. AUC Press, Cairo, pp. 73-98.

23 El-Wazier, K. (2020). Four new mega-universities. URL (accessed 7.7.20).

24 Fahmy, K. (2016). Koll regal el-Pasha. Mohammed Ali we gysho we benaa misr el-haditha (All the Pasha's Men. Mohammed Ali's Army and Modern Egypt Establishing). Dar El-Shrouk, Cairo.

25 Foucault, M. (1994). The order of Things: An Archaeology of the Human Sciences. Vintage Books, New York.

26 Ghannam, F. (2002). Remaking the Modern: Space, Relocation, and the Politics of Identity in a Global Cairo. University of California Press, Berkeley.

27 Ghazaleh, P. (2013). Trading in Power: Merchants and the State in 19th century Egypt. International Journal of Middle Eastern Studies 45, 71-91. 


\section{International Journal of Engineering Applied Sciences and Technology, 2021 \\ Vol. 5, Issue 11, ISSN No. 2455-2143, Pages 83-95 \\ Published Online March 2021 in IJEAST (http://www.ijeast.com)}

28 Ghazaleh, P. (2005). Orginising Labour: Professional Classification in the late Eighteenth to the Earl Nineteenth Century Cairo, in: Crafts and Craftsmen of the Middle East. Fashioning the Individual in the Muslim Mediterranen. I.B.Tauris and Co Ltd, London, pp. 237-262.

29 Ghazaleh, P. (1999). Masters of the Trade: Crafts and Craftspeople in Cairo 1750-1850. Social Science 22.

30 Hakim, B.S. (2010). The Generative Nature of Islamic Rules for the Built Environment. International Journal of Architectural Research 4, 208-212.

31 Hakim, B.S. (2001). Reviving the Rule System: An approach for revitalizing traditional towns in Maghrib. Cities 18, 87-92. https://doi.org/10.1016/S02642751(00)00060-3

32 Hamdan, G. (1993). Cairo. Dar El-Helal, Cairo.

33 Hanna, N., 2011. Artisan Entrepreneurs in Cairo and Early Modern Capitalism 1600-1800. AUC Press, Cairo.

34 Hudson, L. (2008). Transforming Damascus: Space and Modernity in the Islamic City. Tauris, New York.

35 IAURIF and GOPP, (1991). Greater Cairo region master scheme: implementation assessment updating proposals. Ministry of Development, New Communities, Housing and Public Utilities, Cairo.

36 Jordan, D.P. (2015). Paris Haussmann and After. Journal of Urban History 41, 541-549. https://doi.org/10.1177/0096144215571567

37 Kirjakka, M. (2010). Urban Open Spaces in Historic Finish Cities. Presented at the 17th. International Seminar on Urban Form, Hamburg.

38 Kumar, R. (2017). Overview: Social Spaces in Urban Areas. International Journal of Engineering and Technology 4, 1032-1039.

39 Mills, A. (2012). Urban Space and Social Transformation in the Middle East. Journal of Urban History 38, 379-384. https://doi.org/10.1177/0096144211427121

40 Mitchell, T., 1991. Colonising Egypt. University of California Press, Berkeley.

41 Mostafa, H. (2006). The Ceremonial-Urban Dynamic of Cairo from the Fatimid to the Early Mamluk Period (Master). AUC, Cairo.

42 Mubarak, A. (1970). (Died 1893). El-Khetat ElTawfikeya El-Gadida. Egyptian General Book Authority, Cairo.

43 Panerai, P., Castex, J., Depaule, J., Samuel, I., 2005. Urban Forms: The Death and Life of the Urban Block. Architectural Press, Oxford.

44 Pierce, J., Martin, D., Murphy, J. (2010). Relational Place-making: the Networked Politics of Place.

45 Rabbat, N. (2010). Mamluk History through Architecture. Monuments, Culture, and Politics in Medieval Egypt and Syria. AUC Press, Cairo.
46 Rapoport, A. (1980). Human Aspects of Urban Form, Towards a Man-Environment Approach to Urban Form and Design. Pergamon Press, New York.

47 Raymond, A. (2002). Arab Cities in the Ottoman Period: Cairo, Syria and Maghreb. Ashgate Publishing Limited, London.

48 Raymond, A. (2001). Cairo: City of History. The American University in Cairo Press, Cairo.

49 Routledge, P. (2010). Introduction: Cities, Justice and Conflict. Urban Stud 47, 1165-1177. https://doi.org/10.1177/0042098009360240

50 Saad, S. (2020a). Impact of Major Mosques on Urban Street Patterns; Why the Renaissance's Urban Rules must be Applied? International Research Journal of Engineering and Technology (IRJET) 7, 257-265.

51 Saad, S. (2020b). Kahiret el-Thahaworat el-Kobra. (1805-1950) "Great Urban Deformations' Cairo (1805-1950)." Kotobna, Cairo.

52 Saad, S. (2020c). The Myth of Nasser's Arabism. Cairo (1956-1970), a Political-Urban Paradox. International Journal of Engineering Applied Sciences and Technology 5, 37-45.

53 Saad, S. (2020d). Urban Injustice, Socio-economic Neglect and Segregation in Cairo. International Research Journal of Engineering and Technology (IRJET) 7, 2796-2804.

54 Saad, S. (2019)a. El-Kahira el-Tarykheya. Khetabat el-Sametien. (Historic Cairo, Messages of the Silent). Kotobna for Personal Publications, Cairo.

55 Saad, S. (2019b). Cairo in The Age of Great Urban Transformations. Changes in Street Patterns Only, or a Shift in Power Networks as Well?, in: The Future and the Built Environment. Presented at the second International Conference on Islamic Architectural Heritage, Fatih Sultan Mehmet Universitesi, Istanbul, pp. 389-408.

56 Saad, S. (2018). The Spatial Identity of Historic Cairo. Part two: Must Prominent Buildings be Enframed? Presented at the 2nd International conference on Cities' Identity Through Architecture and Art, EREK and Springer, Cairo, pp. 183-194.

57 Saad, S. (2017a). Rehla Fi Zaman el-Madina: El-Helal el Khasyb "A Trip in the History of the City: The Middle East. Cleopatra for Publications, Cairo.

58 Saad, S. (2017b). The Spatial Identity of Historic Cairo. Part One: Typology, Geometry, and Geographic Distribution, in: Proceedings of the 1st International Conference on: Cities' Identity Through Architecture and Art. The Academic Research Community Publication (ARChive), Cairo, pp. 324330.

59 Saad, S. (2007). Spatial Territorialities in Open-end Streets in Historical Cairo, The Major Street as Case Study. Scientific Bulletin of the Faculty of Engineering of Ain Shams University 42, 433-451. 


\section{International Journal of Engineering Applied Sciences and Technology, 2021 \\ Vol. 5, Issue 11, ISSN No. 2455-2143, Pages 83-95 \\ Published Online March 2021 in IJEAST (http://www.ijeast.com)}

60 Saad, S. (Forthcoming). Space, Architecture and Power. Top-down and Bottom-up Placemaking in Historic Arabic-Islamic Cities. Journal of Islamic Architecture.

61 Saad, S., Eysa, H. (2004). Close-end Streets and Urban Territorialities in Historical Cairo. A Quantitative Evaluation. Journal of Engineering Sciences of Assiut University 32, 1859-1870.

62 Sayyid-Marsot, A. (1984). Egypt in the Reign of Muhammad Ali. Cambridge University Press, Cambridge, UK.

63 Selim, G. (2016). Between Order and Modernity Resurgence Planning in Revolutionary Egypt. Journal of Urban History 42, 180-200. https://doi.org/10.1177/0096144214566980

64 Shalaby, A. (n.d). Traditional Urban Process of the Middle East: Lessons in Sustainability, in: Sustainable Architecture and Urban Development. pp. 191-208.

65 Sims, D. (2011). Understanding Cairo: The Logic of a City out of Control. The AUC Press, Cairo.

66 Sims, D. (2000). Residential Informality in Greater Cairo: Typologies, Representative Areas, Quantification, Valuation, and Causal Factors. Institute for Liberty and Democracy, Cairo.

67 Singerman, D., Amar, P. (2006). Contesting Myths, Critiquing Cosmopolitanism, and Creating the New Cairo School of Urban Studies, in: Singerman, Diana and Amar, Paul (Eds.) Cairo Cosmopolitan: Politics, Culture, and Urban Space in the New Globalized Middle East. The AUC Press, Cairo, pp. 1-43.

68 Ufford, L.W. (2007). The Pasha: How Mehemet Ali Defied the West, 1839-1841. McFarland Company Inc. Publishers, London.

69 Uitermark, J., Nicholls, W., Loopmans, M., 2012. Cities and Social Movements: Theorizing beyond the Right to the City. Environment and Planning A. https://doi.org/10.1068/a44301

70 UNESCO, (2005). Good Governance. UNESCO. van der Westhuizen, D., Cloen, J. (2012). Conceptions of Space in the Evolution of a Gridded and an Organic Town: Bloemfontein and Kimberley, South Africa. Procedia - Social and Behavioral Sciences 50, 318332. https://doi.org/10.1016/j.sbspro.2012.08.037

71 Varna, G., Tiesdell, S. (2010). Assessing the publicness of public space; towards a new model. Journal of Urban Design 15, 575-598.

72 Egyptian Authorities for Surveying (1919). The Napoleon Map, 1:5000.

73 The French Government, (1818). 'Planches: Etat Moderne. Mammutfolio, Books 16, 17, 22'.

74 Ministry of Housing, Utilities and Urban Communities (2021). The Technical Report of The New Administrative Capital'.
75 Saad, S. (1994). Die Visuellen und Ästhetischen Faktoren, die die Gestaltung der Städtischen Räume beeinflussen, am Beispiel von Kairo (The Visual and Aesthetic Factors affecting Urban Spaces in Cairo), Unpublished $\mathrm{PhD}$ thesis, the Vienna Technical University. 